\title{
Granting the Future? The Temporality of Cash Transfers in the South African Countryside
}

DOI

http://DX.DOI.ORG/ $10.11606 / 1678-9857$ RA. 2021.186648

\section{Bernard Dubbeld}

Stellenbosch University | Stellenbosch, South Africa

dubbeld@sun.ac.za

ORCID: http://orcid.org/0000-0002-3230-9411

Nos últimos cinco anos, antropólogos do Sul global passaram a considerar programas públicos de transferência de renda como uma alternativa tanto a políticas centradas no trabalho como a projetos nacionais de desenvolvimento. Esses estudos sugerem que subsídios hoje extrapolam o domínio das políticas sociais tradicionais e da burocracia governamental e apontam para um horizonte futuro diante da escassez de trabalho. Esse horizonte tornou-se ainda mais próximo com a pandemia de COVID-19, e com governos, entidades nao-governamentais e da esquerda política reafirmando a importância de uma renda básica universal. Considerando essas discussões, meu artigo tem como foco um programa de transferência de renda na África do Sul após o período do Apartheid, situando um relato etnográfico em relação ao desenho de uma política 'progressista' de subsídios sociais. Apresento a história do trabalho assalariado em relação à renda de famílias africanas, mostrando como as promessas emancipatórias de projetos de transferência de renda foram lidas como um risco a tradições e morais locais. Além da redução de esperanças políticas investidas nas transferências, examino o aspecto temporal dos subsídios, bem como os possíveis futuros que eles evocam. Ao considerar futuros que os subsídios possibilitam, concluo sugerindo que é prematuro afirmar que eles superaram o trabalho assalariado e a sociabilidade que o trabalho acompanha.

ABSTRACT In the past five years, anthropologists from the global South have come to consider public cash transfer programs as an alternative to both work-centered policies and national development projects. These studies suggest that grants today go beyond the domain of traditional social policies and government bureaucracy and point to a new future in view of the scarcity of work. This future has become even closer with the pandemic of COVID-19, and with governments, non-governmental entities and the political left reaffirming the importance of a basic universal income. Considering these discussions, my article focuses on an income transfer program in South Africa after the Apartheid period, placing an ethnographic account in relation to the design of a 'progressive' policy of social grants. I present a longer history of salaried work in relation to rural African households and show how the emancipatory promises of cash transfer projects were read as a risk to local traditions and morals. In addition to this reduction in political hopes invested in transfers, I examine the temporal aspect of cash transfers, as well as the possible futures they evoke. By considering the futures that grants enable, I conclude by suggesting that it is premature to affirm that they have overcome wage work and its attendant sociality.

\section{Transferências} de renda, valor, distribuição, trabalho, futuro, África do Sul 


\section{INTRODUCTION}

Government-funded cash transfers programs have become major points of global discussion amid the covid-19 pandemic. With governments across the globe closing borders, limiting air travel and imposing lockdowns to contain the spread of the new coronavirus, many economic sectors have slumped and individuals have become more economically precarious than previously. Cash transfers have been paid in many places as relief measures, but these payments have prompted questions about whether the latter can become more permanent economic measures, as versions of a universal Basic Income Grant. South Africa and Brazil, as countries with extreme inequality and where cash transfers were introduced as part of left-wing administrations over the last two decades, make good places from which to think about the political promise of cash transfers and their social effects. Indeed, it is thinking from Southern Africa that enabled James Ferguson to urge anthropologists to pay more attention to a new politics around distribution. This attention, he argues, allows us to see that these "sustained expansions in programs of social assistance has led to what could reasonably be described as a new kind of welfare state" (2015: 3). This is a new kind of welfare state because, as he put in an article leading up to the book, it "may have the potential to open up new forms of politics that take us far beyond the limited technocratic aim of ameliorating poverty" (2014: 130) and, as basic income, could be a source of value that "displaces labour".

In this article, I will offer an ethnographically informed analysis of practices around cash transfers in the countryside of the province of KwaZulu-Natal. I will follow Ferguson in examining in particular the connection between welfare grants and wage work, in both its material and its 'moral' dimensions. I will argue that a consideration of both the particular history of wages and households in South Africa, accompanied by an ethnographic focus on the future, may require us to hesitate before accepting that such cash transfers have created the basis for replacing wage labour.

The concern over the connection between welfare and work in democratic states is not merely a scholarly one. As a central element of the United States' 2020 Presidential elections, the campaign of hopeful Democrat candidate Andrew Yang focused on what he called the "Freedom Dividend". This was a proposal to pay all US citizens US $\$ 1000$ per month, independently of their household income. Yang argued that such a program would be funded for by a reorganisation of existing welfare, a $10 \%$ Vat levy, and a tax on the wealth and largest polluters. He also insisted that this form of cash transfer was not 'socialism'. Rather, it would stimulate the market at a time when one-third of all US workers would have been displaced by increased automation. And he suggested that the dividend was important because, unlike previous rounds of capitalist-driven technological advancement, jobs would not be replaced. 
Although Yang's campaign has been unsuccessful, it was striking for a figure aspiring to president of the United States to be advancing the agenda of basic income. It is true that the US welfare system was once central to state policy, which sought to reinforce the labour market (and its assumed nuclear family) by assisting only those who could not work: the disabled, the war veteran, single mother families and the elderly. South Africa had a version of this too: for white South Africans, 20th century welfare policy also sought to aid those who could not participate in the labour market as apartheid sought to normalise and naturalise wage work as the basis of social reproduction. Black South Africans did not qualify for such extensive welfare provision, and were indeed barred from many wage work opportunities, although some limited assistance for those of retirement age and the disabled did emerge during late apartheid in the 1980s.

Yang's campaign was importantly different from the 2oth century welfare in the United States and Europe, and represents a sharp break from the connection between work and welfare and the morality associated with evading work or relying on government. This morality was associated with cash transfers and food stamps in the US at a moment in which welfare loses its political cache in late 1970 s and early 1980 s. This moment pivoted the detrimental stereotype of the African-American "welfare queen", who emerged as a site of fierce racism and right-wing political antagonism, and encouraged popular content based on the morality attached to avoidance of work and reliance on public resources. The notoriety of the "welfare queen" in fact prompted Kimberle Crenshaw in one of her founding essays on intersectionality, to point to this figure as exemplary of how race and gender discrimination operated together: in racial terms, Black Americans were held to be irresponsible members of society for purportedly avoiding work; in gendered terms, women were held to be sexually immoral (1989: 164-5).

In thinking from cash transfers from the global South, thus, I will consider the moral and material terms of social grants, as well as their connections to gendered positions in the household. In advocating for universal basic income, scholars like Ferguson and Guy Standing (2017) point to its promise of not only overcoming dependence on wage work, but also for freeing households from the patriarchal terms of masculine wage labour. In South Africa, as I will suggest, policy makers of the democratic transition in the late 1990 s were attentive to the gendered morality that permeated existing welfare policy, attempting to craft a grant framework that did not affirm the virtues of the nuclear family or marriage. Yet the extent to which they have been successful at avoiding stigmas associated with the receipt of grants, and indeed, how much welfare can be seen to replace wage work, will be a key part of my analysis. In sum, I will think with the possibilities of distribution and new kinds of 'progressive' government practice, and engage with the following questions: how does this dynamic between wage work and grants exist and what kind of sociality is at stake for those, and among those, receiving grants? Do grants 
manage to transcend twentieth century European ideas of social welfare, where state support propped up a labour market dominated by men, reinforcing it rather than replacing it? Does the ethnography of social grants show that their undoubted material importance has created new moral virtues around the value of wage work and decoupled wages from gendered expectations? And, finally, how does viewing cash transfers temporally, in terms of their role in the present and the futures they could serve, allow us to understand what grants enable socially?

\section{MY FIELDSITE}

My research is in the settlement of Clendale, where I did research for about six years, between 2007 and 2012. It is situated on the eastern coastline of South Africa, in the province of KwaZulu-Natal. The settlement is about thirty kilometres from the town of KwaDukuza, which was previously called Stanger and is around 110 kilometres north of Durban. Located at the interior edge of the sugar growing region, the area gradually developed around a sugar mill built the 1890s. Clendale grew into a village around the mill in 1930 s and 1940 s and for most of the twentieth century was largely inhabited by the descendants of indentured cane workers brought from India.

About six kilometres further into the interior from Clendale lies areas designated under Apartheid as Zulu, initially named "Native Reserves" and later "Bantustans" during segregationist and Apartheid administrations. By the 1960 s and 1970s, the Indian inhabitants of the settlement worked predominately in the mill or as overseers in the cane fields. isiZulu speaking workers - together with a minority of Africans who hailed from the Eastern Cape — did much of planting and harvesting and many required to travel back and forth over the Apartheid border on a daily basis. During this period, the Sugar Company, Lonrho, invested in the roads of the area, ensuring that these were tarred, thereby connecting the village to Stanger and ultimately to Durban and beyond. The roads beyond Glendale, to the African homelands, remained dirt roads.

With the coming of the democratic dispensation in 1994,

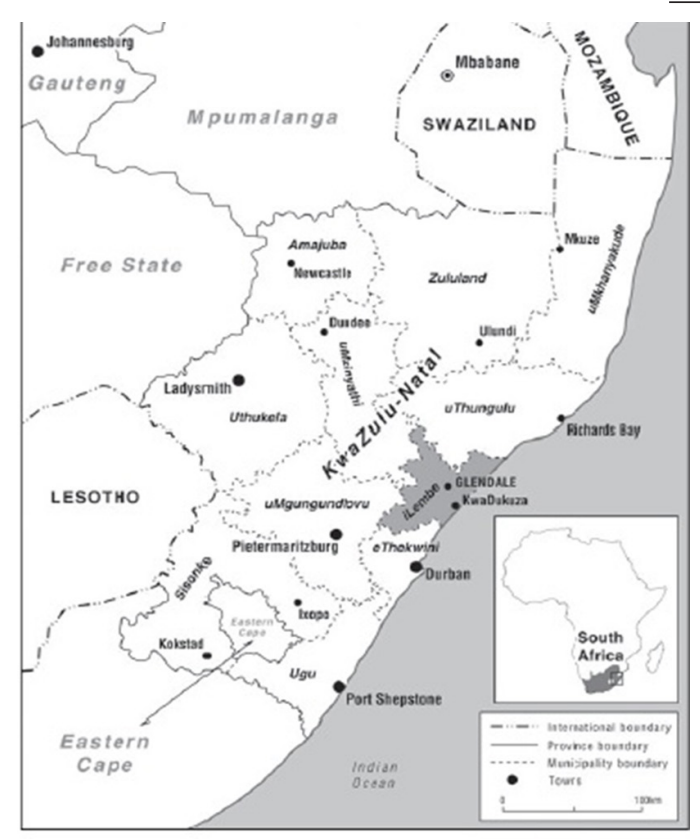
the sugar company donated a significant tract of agricultural land to the state to build housing near the mill. Well
Figura 1

Clendale's location in KwaZulu-Natal, and in South Africa. Taken from Dubbeld (2013a, 499) Copyright Cambridge University Press. 
before the building work commenced on these houses, in 1996, the mill was bought out by a rival sugar conglomerate and shut down. That company, Illovo Sugar, retained most of the area under cane but brought in their own workers at planting and harvesting time, which continues to this day. They only employ a few locals casually, at the times when the work becomes the most intense. Following the closure of the mill, most of the Indian inhabitants of the area left, but building on the housing settlement continued, and 400 hundred houses were completed as part of the first phase of what has become known as RDP - Reconstruction and Development Programme - Houses, in late 2001, with people taking residence early the following year.

A house was thus given by the newly democratic state to many who had only recently become full citizens of the country. Infrastructure in the area was improved, with the houses electrified and running water and outside toilets accessible to each house, and a local government sponsored rubbish removal service was introduced. Private buses and mini-bus taxis run to area regularly, many of them transporting school children to high schools or people visiting relatives, or going off to grant paypoints and supermarkets, as the area has only very rudimentary shops that are run out of their houses.

A few folks living in the houses are employed elsewhere, whether more regularly or in occasional piece work. Some do get seasonal casual labour on the sugar plantations, but most of the time, the vast majority of people here are unemployed, and this settlement, is for them, a place of a house but without employment. My informants estimated that unemployment here is between seventy and eighty percent. People rely on cash transfers: the child support grant given to care givers of children until 18 years of age, the pension, offered to those deemed beyond working age, with a few receiving a disability grant. As one informant, Thokozani, memorably put it:

People in Glendale live on pensions [grants]. There are no jobs. The Child Support Grant and the pension... you have a child and you get this pension... if you are a granny they will take you, and register you, they take you and eat your money. ${ }^{2}$

By way of introducing the settlement, there is one further important point to note about the kinship and family configurations. The roughly four hundred RDP houses are permanently home to one or two elderly folks, often with a grandchild or two, or a woman on her own with between one and three children. Sometimes single men inhabit the houses, and every now and again you might encounter three generations, but in those cases some part of the middle generation is always missing. If you spend enough time in Clendale, though, you sometimes see absent figures emerging. At Christmas, the settlement swells. ${ }^{3}$ It is especially young men who seem to return then, marking their presence by standing on streets, talking loudly, or drinking merrily. Even though the absent kin of Clendale's homes, especially young men in their twenties,
2 | In our discussion Thokozani continued with the idea that even after grant holders die, others might continue to receive their grants illicitly. For more analyses of the implications within households of continuing to use your relatives grants after their passing (literally put as "eating your ancestors") see Dubbeld (2013b: 213).

3| There is an interesting comparison to be developed with Zolani Ngwane's (2003) analysis of the rural African household during Christmas during the time of Apartheid Migrant Labour. In a preliminary sense, a major difference is the incomes of returning men is vastly different: in the prior time, men had regular jobs, whereas today, income for these men is much more irregular. This further complicates men's attempts to claim rural domestic space. 
thirties, and forties, do return to the village much more often than at Christmas time, they do not all return at the same time or with the same revelry. Indeed, these men are largely held to be absconders, regarded as unwilling or unable to provide their families with material support and often absent. But unlike men who were absent from their families during apartheid, these men don't have regular work and are often without money: they move between piece jobs in urban area face long periods of unemployment, and occasional dabble in petty crime. ${ }^{4}$ They may have other intimate relations elsewhere, but there were seldom stories of men having established second families. Although some elders and women do want these men to return to Glendale on a more permanent basis and to assume responsibility for raising the children they fathered, many also believe that these men might disturb its residents. As we shall see, what makes this more even complex is a curious relation to the state itself, which is regarded as unnecessarily 'freeing' women from needing to rely on men, and of being responsible for the corruption of the social order itself. But before elaborating this in relation to local aspirations for the future and the positions of grants, we need to understand how grants exist in South Africa, as well as some of the social history of wage work and households.

\section{SITUATING SOUTH AFRICAN SOCIAL GRANTS: REINFORCING OR REPLACING WAGE WORK?}

Very briefly, during first five years of the democratic administration, the government set a commission to work to develop a new social policy framework that would re-make Apartheid forms of social welfare. ${ }^{5}$ By the end of 1990s, the South African government offered a far more extensive system of social grants than previously, providing support to the elderly, the disabled, and caregivers of children. ${ }^{6}$ Central to this reorganisation was the Child Support Grant, which replaced the previous "Family maintenance grant" and was given regardless of martial or familial status to the parent or guardian of a child. Such caregivers are eligible if they earn under R48000 per year (R4000 per month) if they are single or R96000 annually if they are a married couple.

The numbers of grants have increased dramatically over the last decade, with close to eighteen million grants paid out in $\mathbf{2 0 1 8}$ compared to only three million in 2001 (Statistics South Africa, 2018). This increase is even more substantial for the Child Support Grant, with one million grants in 2001 becoming almost twelve and a half million in 2019 (South African Social Security Agency, 2019).

At a quantitative level, a major study has shown that social grants have improved childhood nutrition and school attendance among the poorest South Africans (DSD, 2012). But if we focus on the relations between grants and work, a slightly different picture emerges. It is not only that the number of grant recipients are increasing, it is also that the labour market in South Africa is unable to expand sufficiently to
4 | During apartheid, the contrast between migrant labourers who were employed over the long term and regularly provided income for rural households, those who absconded from kinship obligations and settled in urban areas was clearly marked in many isiZulu speaking communities. The immediate post-apartheid period, Hylton White (2004: 154-7) traced the appearance of a new contrast, between the absconder(itshipa). whose fault was selfishness not his work ethic, and the thug (tsotsi), who preyed on those who worked and occupied an unambiguously immoral position. In more contemporary Clendale, there are few absconders who are able to build a life through work elsewhere, and instead many men are regarded as falling between all these positions: sometimes returning with kin with some money but remaining away for long periods and sometimes suspected of criminal activity.

5| In the mid-1990s the government appointed the Lund commission to investigate family and child support. Following their recommendations, in 1998 the government implemented a reorganized welfare policy, offering a far more extensive system of social grants than previously, providing support to the elderly, the disabled, and caregivers of children. The Child Support Crant is by far the most common, and is a noncontributory, largely unconditional transfer, other than a means test for which caregivers of children under 18 qualify if they earn under R39600 per year (R3 300 per month) for singles, or a combined income should not be above R79 200 per year (R6 600 per month) for married couples. This grant is R430 per month.

6| The other grants are significantly larger than the Child Support Grant, with the Old Age, Disability, and Care Depending Grants at R1860 per month, and the Foster Care Grant at R1040 per month. 
reduce unemployment. Even the conservative official unemployment rate has hovered between $22 \%$ and $27 \%$ of working age adults over the last fifteen years, with a vast number of people being classified as "not economically active" and thus not counted in the official rate. As long ago as 2013, the South African Institute of Race Relations suggested that "more people are receiving social grants than working", noting that less than fifteen million are employed, and even some growth in the absolute number listed as employed in the years thereafter still revealed that considerably more people were unemployed than those that held jobs, and that the total number of grants paid continued to exceed official employment figures (Jones, 2013).?

The Institute of Race Relations claim is not the only instance or way that South Africans are raising the comparison between wage work and grants. On many occasions, this relation is raised as a matter of the anxiety of how grants should be funded, which stresses how taxpayers - whose income arises predominately but not exclusively from formal wage work - might be able to pay for growing numbers on welfare. For instance, some conservative economists argue that the South African economy is already massively redistributive, transferring money from skilled workers to those who were unskilled and un-employable, and thus suggesting the state grant expenditure cannot grow without a growth in the labour market, or without even higher tax burden being placed on those earning wages (Hlatshaneni, 2017). Despite these uncertainties regarding the government's capacity to pay for grants during the covid-19 lockdown, the government did manage to offer an additional amount of R300 for every child support grant in May and an unemployed grant of R350 per month from May to October. ${ }^{8}$

Despite this latter grant, revised social grant policy has not explicitly sought to address unemployment, repeating, as Jeremy Seekings (2008) has argued, an older European social welfare idea of "just dessert", rewarding only those whose ability to work is directly compromised rather than acknowledging that full employment is unattainable. That is, even if social grants in South Africa have had the effect in practice of ameliorating poverty for many, including leading to improved childhood nutrition and school attendance, until the covid-19 lockdown, there was no acknowledgment from the government that they ought to be responsible for the unemployed.

But until now, there has also not been a popular demand for a universal basic income grant. Liz Fouksman's (np) recent research traces popular sentiments among the urban poor around differences between grants, decent work and so-called "bullshit jobs". For Fouksman, a moral logic around just dessert is not only a state discourse, with many in urban poor regarding decent work as a goal and financial reward of such labour a just outcome, and of greater moral worth than government cash transfers. To some extent, both Seekings and Fouksman show how social grants in South Africa, whether as policy or as lived, do not manage to overcome the value of wage work, with distinctions emerging between certain forms of wage work as a goal for individuals against social grants, which hold far less prestige.
7| As caregivers can receive more than one Child Support Grant, in 2013 it was the case that the total number of grants exceeded the total number of those formally employed, even if this did not immediately mean that more people were receiving grants than those employed. By 2016, however, the SAIRR report notes that "there were 15545000 people with jobs in SA, while 17094331 people were receiving social grants." (Hlatshaneni, 2017).

8 | For Child Support Grant recipients, between June and October, a flat increase of R500 was paid to households regardless of how many children in the household were being supported by the grant. 
From the vantage point of more rural setting than Fouksman's study, I will suggest that the moral distinction between holding a job and receiving a grant also exists and expresses a particular gendered character that in some respects mirrors the stigmatization of the "welfare queen" in the United States, even as popular antagonism is often projected onto the government itself. Interestingly, though, while the policy of putting money directly in the hand of care-givers can be considered part of a "neoliberalisation of the state," for those in Clendale it is government that is blamed for its social effects rather than on individuals, whether errant men or grant-receiving women. Indeed, as I will show, grants become a site for a debate over the future, what the state's role will be, and how receiving cash transfer as opposed to holding a waged position might shape how the future can be imagined and how the present is lived.

\section{THE SOCIAL HISTORY OF MIGRANT WAGES AND HOUSEHOLD DISTRIBUTION}

To understand the effects of the grant and its relationship to work in Clendale, we need to know more than about changes in the post-apartheid welfare policy. In the South African countryside, the social history of wages in the region grounds the connections between money, households and futures. Wage labour was perhaps one of the most studied dimensions of the lives of black South Africans in the twentieth century. In the 1970s and 1980s, many Marxist-inspired social scientists inspired the reconsideration and rewriting of late 19th and 2oth century South African history as an expression of class domination, where capitalism grew in South Africa from the immense profits secured through the ultra-exploitation of black men made into a protoworking class (Wolpe, 1972; Marks \& Trapido, 1979; Morris, 1976; for an engagement with some of this literature, see Dubbeld, 2019). Known as Marxist revisionists, they analysed how the racist state served to protect such exploitation and secure whites as a protected bourgeois class. This approach emphasized how African households were compelled by colonial authorities at the end of nineteenth century to pay tax and thus force men into wage labour. While these scholars pointed to the resistance that this produced, later historical studies showed how wages earned by young men allowed them to challenge the authority of their fathers over the household and in deciding their marriage partners (Carton, 2000; Harries, 1996). These analyses ultimately pointed to how wages became a solvent of traditional African social bonds, making the possession of this money the basis of new terms of marriage negotiation and household authority. Kinship was thus understood as becoming functional to capitalist exploitation, but no longer organized society, which was dominated by money, and for Africans, earned through a racist, ultra-exploitative form of wage labour.

However, anthropological scholarship that relied on fieldwork undertaken in the 1980 and 1990 s contested the linearity of such accounts, showing how "tradition" instead remained a fertile notion "to think with". This came in the context of wage 
earners often demonstrating less interest in becoming an urban working class than in investing cash in rural homes and property as a means of securing social reproduction and future. Hence Ferguson's own very early work (1990) showed how migrant men continued to invest in cattle after a drought made it appear economically irrational to do. What he identified as form of "bovine mystique" revealed how wages spent on cattle secured privilege in homesteads even when cattle proved to be insecure investments. More recently, Hylton White (2010) showed how migrants continue to use their wages as investments in building homesteads to enabled men to die properly, and so become honourable spirits.

There are two ways this literature offers an alternative interpretation of wages. First, I want to point out that wages are used by men in Clendale to purchase privilege in their households and, to use Ferguson's term, a "counter-distributional" economy happens in the home with men investing their wages in cattle that women cannot access. While some portion of their income was surely distributed into households, those working considered themselves as having a right to much greater share of their wages than their female partners or children, a greater share with was bound up with sustaining the hierarchy of the home. In another words, money was not just money: money as a wage earned by some enabled certain kinds of distribution and foreclosed others.

The second point is that the money that men kept back from the household is particularly oriented towards their futures, insofar as they are used to ensure their exclusive use in retirement or in death. We could say, perhaps not unlike The Protestant Ethic (Weber, 1930), that for these men, as oppressive as work was when considered structurally, its regularity and security created future-oriented subjects concerned with planning their destinies (even if such planning in Weber was a paradoxical psychological product: an attempt to create certainty amid the absolute uncertainty of predestination).

I will show below how both household distribution and future-oriented action become serious questions for those receiving grants in Clendale. I will argue that these questions complicate our consideration of the replacement of wages by welfare grants at economic, social and conceptual levels. Ferguson's (2015) rendering of the conditions which render cash transfers political and enable new possibilities for distribution begins with the transformation in the demand for labour, from what he calls labour scarcity to a massive labour surplus. While he accepts to the revisionist Marxist account -- that capitalists were able to pay lower wages because the state prevented African families from living in cities and thus in effect rural African families thus subsidized capitalist profits - did describe relations for much of the twentieth century, he argues that this kind of analysis of value has little relevance in the present. He contends that this is a moment when "a restructured capitalism has ever less need for the ready supply of low-wage, low-skilled labourers than the migrant labour system generated, and thus that marginalization and impoverishment of so many is "a sign of their very limited 
relevance to capital at any scale", and therefore that the attempt to develop an analysis from the exploitation of labour has limited analytical purchase (Ferguson, 2015: 10).

Ferguson's point then, is that as work has become scarce, so the reach of accounts of capitalism in describing the lives of poor South Africans has been exhausted. This is central to his argument, and for him needs to be pushed even further by overcoming our patriarchal preoccupation with men as workers through extending the grant to all unemployed. But, as I will describe below, it is less clear from Clendale that welfare will establish equality in households, whether in its current form or in the ideal version that Ferguson is urging us to adopt. And while he is correct that an analysis focuses on exploitation cannot account for those outside wage labour and receiving grants, my analysis will point to ways in which capitalist forms of value may continue to play a role in the lives of people who are unable to work - offering aspirations that orient their practice towards building a future that seeks to secure rather than to surpass wage work.

\section{DOMESTIC DISTRIBUTION AND THE SOCIALITY OF SOCIAL GRANTS}

In Clendale, the settlement that I described at the outset, most live in government houses, rely on government infrastructure and where many rely on government grants rather than wages. The distribution of the grant here has resulted in women with young children a measure of independence from men and elders, and many can live independently of men. As I have already noted, men, by contrast, attempt to avoid their dependence on women, with many more erratic residents of the settlement, often leaving to try and find bits of work in larger centres outside the settlement. This pattern is not entirely unique to Glendale. In nearby, more urbanized Mandeni, Mark Hunter (2010) noted a range of precarious practices that have emerged in the 'domestic sphere', emphasizing the changing character of sexual relations and the growing (relative) independence of women.

It has not followed from this material fact that people have adopted new moral horizons or regard themselves as earning shares. Many see the grant as closely tied to the state and to their experience as democracy. Some in the settlement read the social and economic transformation since democracy as inadequate, with grants woefully inadequate to address material needs, as many are very poor and ill in the settlement, even if they have houses and electricity. Indeed, their common refrain was that more comprehensive interventions from the state are required, most powerfully, that the government finds them employment. Crucial here is that infrastructure or grants was regarded as kind of immediate aid, and accepted as some degree of help, but was not seen as a 'solution' that people imagined the building of a mall and creation of employment opportunities would offer.

Other people felt the changes the government made after apartheid were in the wrong direction, supporting the rights of children against parents, protecting criminals 
against honest citizens, and undermining the moral order (which they implied was of strong families headed by assertive fathers). For this second group, it was social grants - viewed as hand-outs to those who were not deserving - that corrupted the moral codes of the respectable house by providing younger mothers with a measure of autonomy from men and from elders. In a curious way, some in the settlement, including some women, repeated a version of Welfare Queen trope from the United States, blaming the state for subsidizing the irresponsible behaviour of young women who ought to have followed a more respectable path to adulthood, including listening to their elders and finding wage work. Here, unlike in the United States, they were derided for not being proper mothers - insofar as they were unable to keep relationships together - and for not being proper youth -insofar as they were willing to refuse their own parental care. Here, again, it was the democratic state whose grant policy did not aid appropriately — working against what was regarded locally as a normal-i.e. patriarchal-order of society.

We might say that social grants provided a register through which people in Clendale spoke of community and morality in much the same way wage work does or did. Of course, some, like Dodakazi, a younger woman with a child who is able, through the grant and the house to live independently of her parents and the estranged father of her child, do recognize the value of grants in transforming their lives. I will return to her later. For now, I want to dwell on how we understand the ambivalence many people in Glendale feel towards grants. For one thing, it is clear here that the absence of wage work and the presence of grants has not transformed moral languages around the value of paid and unpaid work. Men without wage work are regarded as without value, as ineligible for marriage. Some people in the settlement say that the government has replaced men, and it is as if they are married to them. And this sentiment, of men being regarded not only as economically but also as socially superfluous due to their lack of work and the government becoming women's spouses, as Leslie Bank (2011) has discussed in his ethnography of East London and its townships, is not confined only to Clendale.

This leads me to suggest that these men experience a kind of double superfluidity, largely unable to find long-term wage work and from secure positions in households. Indeed, adult men who are not eligible for the pension grant and remain in the settlement claim to feel restless, and as having to find something, so as not to let their families down. This sense of moral responsibility for material provision almost seems to be a condition of adulthood for men here, as if not being able to provide means that these men remain boys socially.

Certainly, at the level of policy, we could argue that the transformation from wage work to welfare could only be completed if grants were paid to all those unemployed, or indeed to everybody. This would remove the language of 'desert' that was foundational to British welfare policy of the 1940s, which has remained a feature of post-apartheid welfare policy, despite its other progressive dimensions. 
But there is a further difficulty, with relates to the extent that work - even in its absence-remains recognized as a source of material and moral value. To illustrate: for people receiving the grant in Clendale, marriage is not viable prospect, because here and in many other locations in South Africa, marriage is a process that involves long term financial investment, and is not only an event. Such an investment is beyond those receiving grants, and it is not clear that extending grant to unemployed men would solve the difficulty. Indeed, marriage remains a preserve of the employed. In this sense, we might say that as astute as Ferguson is in identifying the patriarchal politics of wage work, it is not clear that even when many do not have wage work, such patriarchal norms disappear. Perhaps, indeed, such patriarchal norms reflect that there are two economies, one of the wage and the other of welfare, that the waged economy is a place of relative freedom to consume, and is still identified with the success of men.

To put this slightly differently: how might a grant system that diminishes the importance of particular kinds of social relations be able to establish a sense of mutuality in which relations to a collective whole are emphasized, where people might actually be able to recognize their individual good in the common good? There is little doubt of the political importance of the insistence of the Lund commission that framed post-apartheid welfare policy that the nature of the family should not have any bearing on the payment of grants. But does the critique of the nuclear family end up erasing the possibility of recognizing any social relations at all, other than that between mother and child? Or in a grant arrangement like the one that Yang and Ferguson suggests, does it erase all social relations other than those between the state and the grant recipient?

I am gesturing here to how the grant might unwittingly produce an extremely individualized set of social arrangements that looks like neoliberalism and in which something like a collective belief in common shares-which Ferguson emphasizes can be an outcome of generalised cash transfers-- becomes more distant, rather than closer? I should add that, since the end of Apartheid and the massive expenditure on grants, all kinds of public care facilities, including creches (or childcare centres), public clinics and hospitals have been neglected by the state and hence that the grant system has become an especially individualized system of distribution.

In reading the reform of service provision after Apartheid, several scholars have pointed to the technopolitics of the contemporary South African state. Von Schnitzler (2015) focuses on changing regimes of water provision in Johannesburg and argues that the installation of individual meters tracking consumption have transformed citizens into individual consumers, bypassing the possibility for different kinds of collective subjectivities made possible in the anti-apartheid struggle. In different studies, Vally (2014) and Torkelson (2020) have demonstrated individualising, neoliberal dimensions to grant pay-out, with the latter showing how creditors have been given access to grant recipients and are able to claim significant amounts from small pay-outs to service debt. 
In Glendale at least, this individualizing system of grants has not entirely diminished people's relation to the state into a technical matter: people regard the government as having a burden of public care and take seriously its slogan since 1994 of "a better life for all" (Dubbeld, 2017). Nor has it surpassed a sense of collective sociality here: expressed at times in terms of culture held to be collective, at others of a suffering that is seen as more than individual, and finally, and perhaps most prominently, as a set of moral codes that refer to how relationships between partners, within households, and within society more generally, 'ought' to be conducted.

One might characterise the governing strategy as combining some embrace of neoliberal techniques with a commitment to long-term collective social transformation. Of course, the state is neither fully coherent or politically united machine, and it has become increasingly apparent that the different divisions of government do not always work together practically, let alone ideologically. Nevertheless, the government's policy commitments to progressive transformation cannot be reduced to mere surface discourse beneath which neoliberal economics flourishes.

Having said this, it is clear that while social grants in their current form do put pressure on older forms of socialities characterised by extensive gendered and generational hierarchies, they do not necessarily yield unambiguously freer sets of social arrangements. Indeed, it is useful to read this in relation to Fraser's recent work (2016) on the contradictions of capital and care, in which she argues forcefully that new challenges around care in the 21st century need to be seen in relation to the flexibilization of capitalism and to the erosion of public services. This means that although contemporary economic systems have promised more freedom and autonomy for women, they have also pushed the burden of care back onto households, away from public institutions. In effect, to reproduce themselves, households frequently require both men and women to work longer hours, and either to pay for newly commodified care work, or to neglect care for families.

Another way to approach the effects of grants socially is to regard them not only in terms of how they articulate with already existing norms of social life in Clendale, but in how they might be understood in relation to local notions of the future. In this respect, I will turn to how government grants (and infrastructure) are regarded in the present, and how imaginaries of a better life approach them.

\section{THE TIME OF SOCIAL GRANTS}

Thus far, I have suggested that social grants expose a tension in households in Clendale, where men are expected to provide for families and do not have the material means to do so. With the income received from social grants-and the child support grant in particular-offering the means through which households survive from one month to the next, this has exacerbated the pressure on men to provide and many 
have left their homes in the attempt to do so, with casual employment possibilities far more likely in urban areas than in the countryside. This has left households somewhat fractured along lines of gender and generation, with men more transient members of households than others. If the transience of men from rural households is nothing new - now men are far less likely to provide materially than under conditions of migrant labour. This has led, in turn, to a certain ambivalence towards the state and its new laws and grants seen as providing much needed material aid, but also in contributing to a moral decay at odds with the government's promise of providing a better future.

This raises the temporality of grants, and the futures they offer as material emblems of the democratic government. Certainly, we know from the earlier studies cited above that money was used in a different ways, and that certain forms of income that men earned was reserved for investment in cattle or the building of homes that attempted to secure the future of men in retirement or as ancestral spirits. But can grants be used in this way? Ethnographic research by Gregory Morton (2019a, 2019b) in rural Bahia, Brazil, has pointed to the ways in which different kinds of income, including money from maternity grants and Bolsa Familia is allocated, to different temporal projects, with shorter and longer-term horizons. How does this look in Clendale?

In the most immediate sense, the government grants received by elders and mothers match the temporal cycles of wage labour, insofar as they are paid monthly (although as we shall see, the future implied by wages and grants is quite different). For elders, then, timing of grant payments means that they can imagine a waiting that corresponds to earlier times in which younger men earned wages and saved up for building homes and marriages. For mothers, by contrast, the grant is something that cannot be saved or accumulated. Much of it is spent on receipt: on dry foods that might last the month, on, nappies or formula when there a baby to care for, on electricity and on pre-paid airtime to stay in contact with relatives and errant partners, and on servicing debts. For the adult men who do not receive grants, the payment cycles are monthly reminders of their incapacities to be adequate members of the household.

Despite the resemblance between receiving a monthly wage and a monthly grant, there are some other temporal distinctions between the two. First, on the wage side, permanent work is exceptional here, and becoming more scarce across the country's economy as a whole. This means that the cycles of money from work is more constrained and uncertain. People spend a lot of time waiting for a job and then may work in short bursts or in longer cycles. But second, on the grant side, if the monthly cycle of payment does offer a certain regularity, its longer-term promise is limited, both by the meagre amount of the grant and by the fact that there is no possibility for advancement. Whereas wage work promises a greater future, the grant offers a kind of status.

I want to illustrate this point by referring to a few of my informants. Dodakazi is a twenty-year-old woman who is a mother of a three-year-old son. She lives with him 
in a house that she calls her own and receives the child support grant. When sugar cane is being planted nearby she sometimes gets seasonal, day work administering pesticides to the cane. She carefully saves any money from this work, as she says she cannot save much from the grant at all. She receives no other income, either from the child's father or from her parents. She chooses not to demand maintenance because she says they are estranged, he moves around a lot, and never has a regular income. She also does not rely on her parents, as she moved out of their home and into her own house after a squabble over her romantic choices, and suggests that she does not wish to be obliged to her parents, indeed, claiming that she would rather be poor than submit to her mother's authority.

She acknowledges that the government house and the grant allow her independence from her elders, but paused uneasily when I asked her about future plans. She wants her son to go to the best possible school, and to stay in school, she said. The primary school in the settlement would be okay, but thought that, by the time he attended high school, "things should change". I asked her to elaborate, and she suggested that somehow she needed to earn money to secure her child's future, and simply could not make enough in Clendale. I asked her about the informal trades some people run out of their houses, but she suggested that there were already too many of them in a community without much money. No, she affirmed, by the time her son reached high school she would have make another plan to find a better income, and to do this she would either have to reconcile with her parents and share costs, or move to another place with greater prospects of employment.

Of course, many of my informants did have children in high schools and most tried to send them to a school twenty miles away rather than to the rural school in the neighbouring district about three miles away. Although the school further away asked no fees, parents have to buy bus tickets for their child every term, taking a significant sum out of their small grant. Nevertheless, a number of parents told me of how they would attempt to save for this ticket, asking grandparents and other relatives who might be receiving pensions for small contributions.

Makosi, for instance, sends her granddaughter, Busi, to the high school twenty miles away, in the town of KwaDukuza. She says that "many children did not finish school, and are now in their twenties; so many people's children are just sitting around." Some, she says, even finished school, but remain stuck. She maintains that the only way to avoid this, and to find a future, is to study until a high grade and then at tertiary level. Stembiso elaborated this point: noting that

"children finish grade 12, [but] there is no job... there were lots of job opportunities during apartheid. There was oppression but we got jobs, and were able to take care of our families. Now school is not enough."

People's concern about educating their children revealed an important insight into the character of today's labour market. It is not only that unemployment in 
the country is extremely high, it is sharply differentiated. That is, while it is almost impossible to find regular employment without a post-school qualification, there are lots of positions available to those with advanced or specialized skills. (Kraak, 2008). That parents in Clendale are willing to make investments in their children's education using whatever means they can obtain reveals an awareness of the narrowing chances of work for the less educated.

It also tells us about how people understand grants, and their particular temporality. For even when grants prove successful in achieving their goals of protecting some of the most vulnerable South Africans, people like Dodakazi and her son, people find that they cannot craft a future through grants. Indeed, informants openly say that grants and the other government things they are given can do little more than maintain them for now. For life to be better, and indeed to realize the promise of post-apartheid government of "a better life for all", people in Clendale aspire that their children escape from the government grants. That is, the only means for them to imagine a future is precisely beyond the grants that maintain them in the present, and towards finding a future in wage work.

\section{CONCLUSION}

In this paper, I have discussed two aspects of social grants as they are received in Clendale: their distribution and how they are experienced in time, especially in relation to the future. While the distribution of grants after apartheid appears to ameliorate some of the hardship for the most vulnerable in South Africa, it has also prompted new moral anxieties around who the democratic state ought to be assisting, and in whose pockets these grants enter the household. If especially gendered and generational tensions over the distribution of money into poorer households is not new, the fact that this cash emanates from a state that has promised a break with the past and a better life has produced ambivalence and even anger at the government.

At a conceptual level, of course, anthropologists such as Ferguson and Tanya Murray Li (2017) have urged that we take account of new distributional regimes. They engage such regimes both at the level of what cash transfers are currently, and what they may become as political possibilities in a changed contemporary political economy. While Ferguson draws on the genealogies of gift exchange in arguing for the possibilities of new kind of political arrangements after wage and production, Li has argued that concepts of development, replete with teleologies of progress that have dominated thinking about the global South from the post war period, need to be replaced by a concern with distribution. Distribution, for $\mathrm{Li}$, can be the basis of a politics that addresses what she understands to be the detritus of contemporary capitalism, which has left ever greater numbers as "surplus populations." For both Ferguson and Li, then, the promises of capitalist social inclusion through wage work, enabled by a developmentalist 
economic framework, is anachronistic. Instead, we need to address distribution as a political question that can enable new kinds of social membership. And it is in the global South that we can look to these frameworks as already being engineered.

While I am sympathetic to the campaign of extending cash transfers to the everybody, my concern in this paper has been with how grants exist and the kinds of possibilities they engender. These grant recipients, their kin, and even the working age men from the area that are excluded from receiving such state support, encounter a capitalist market which not only renders them surplus, but provides them with an experience of the lack of means to achieve prosperity. Labour power, even in its absence, structures value in contemporary times. This is made clear when people consider the future for themselves or the children, they do not regard the grant, even if its distribution became unconditional and it was increased, as they means to make a better life. At best, it can provide a means for them to help their children to imagine a future beyond the state, beyond the grant, in wage work. Their future, then, as "a cultural fact" (Appadurai, 2013), remains tied to wage work, in a situation where wage work appears to be the only reliable means of upward mobility. ${ }^{9}$

Bernard Dubbeld teaches at the Department of Sociology and Social Anthropology, Stellenbosch University in South Africa. He is completing a book manuscript entitled "Unsettled Futures: the paradoxes of the post-apartheid project".

ACKNOWLEDGEMENTS: I would like thank Laura Moutinho, Thais Tiriba, Paulo Neves, Thomas Cousins, Liz Fouksman, David du Toit, Tapiwa Chagonda, and Fernanda Pinto de Almeida for valuable comments at various stages of the writing of this paper. All errors remain my responsibility.

AUTHORS' CONTRIBUTION: Not Applicable

RESEARCH FUNDING: Not Applicable

\section{BIBLIOGRAPHIC REFERENCES}

APPADURAI, Arjun. 2013. The Future

As A Cultural Fact. London: Verso.

BANK, Leslie 2011. Home Spaces,

Street Styles. London: Pluto Press.
CARTON, Ben. 2000. Blood from your Children. London: The University of Virginia Press.

CRENSHAW, Kimberle. 1989. “Demarginalizing the Intersection of Race and Sex: A Black
9 | In calling for anthropology to study the future as a cultural fact, Appadurai has argued it needs to be approached it "as not just a technical or neutral space, but shot through with affect and sensation" (2013: 286-7). I would add, that we need to think of how the value dimension - at once economically and culturally-- mediates these affects and sensations. 
Feminist Critique of Antidiscrimination

Doctrine, Feminist Theory and

Antiracist Politics," University of

Chicago Legal Forum: V. 8: 139-167.

DEPARTMENT OF SOCIAL DEVELOPMENT, South African Social Security Agency, and UNICEF 2012. The Child Support Grant Impact Assessment. UNICEF. Available at: https://www.unicef.org/southafrica/ media/1116/file/ZAF-South-African-childsupport-grant-impact-assessment-2012.pdf,

DUBBELD, Bernard 2013a "Envisioning Governance". Africa v. 83, n.3: 492-512.

DUBBELD, Bernard 2013b. "How Social Security becomes social insecurity". Acta Juridica, v.1: 197-213.

DUBBELD, Bernard 2017. "Democracy as Techno-political Future". Anthropology Southern Africa. v. 40, n.2: 73-84.

DUBBELD, Bernard. 2019. "After revisionist Marxism". Transformation, v. 100: 128-152.

FRASER, Nancy. 2016. "Contradictions of Capital and Care:. New

Left Review 100: 99-117.

FERGUSON, James. 1990. The

Anti-Politics Machine. Minnesota:

University of Minnesota Press.

FERCUSON, James. 2014. "The Social Life of "Cash Payment": Money, Markets, and the Mutualities of Poverty". In: FISHER, Edward. (ed) Cash on the Table. Santa Fe: SAR Press

FERGUSON, James. 2015. Give a man a fish. Durham: Duke University Press.

FOUKSMAN, Liz. (np). "Who deserves social protection?: Moral logics of worth, deservingness and distribution among the South African unemployed". Seminar Presentation, Department of Sociology and Social Anthropology, Stellenbosch University. 5 March 2020.

HARRIES, Patrick. 1996. Work, Culture and Identity. Portsmouth: Heinemann.

HLATSHANENI, Simnikiwe. 2017. "Social Grants are 'unsustainable”. The Citizen. 22 June. Accessed at: https://citizen.co.za/ news/1548583/social-grants-unsustainable/

HUNTER, Mark. 2010. Love in a time of Aids. Bloomington: Indiana University Press.

JONES, Michelle. 2013. "More people on social grants than working". Cape Times. 28 June. https://www.iol.co.za/news/south-africa/morepeople-on-welfare-than-working-1539021

KRAAK, Andre. 2008 "A critical review of the national skills development strategy in South Africa." Journal of Vocational Education and Training v. 60, n.1:1-18.

LI, Tanya Murray 2017. "After Development: Surplus Population and the Politics of Entitlement" Development and Change v.48, n.6: 1247-1261.

MARKS, Shula \& TRAPIDO, Stanley 1979. "Lord Milner and the South African State". History Workshop Journal v. 8: 50-80.

MORRIS, Mike. 1976. "The development of capitalism in South African agriculture: class struggle in the countryside".

Economy and Society v.5. n.3: 292-343

MORTON, Gregory 2019a "How Work Counts: Time, Self-Employment, and Wagelessness in Rural Brazil". Anthropology Quarterly v. 92, n. 3: 663-696.

MORTON, Gregory 2019b "The power of lump sums: Using maternity payment schedules to reduce the gender asset gap in households reached by Brazil's Bolsa 
Família conditional cash transfer".

World Development v. 113: 352-367.

NGWANE, Zolani. 2003. '“Christmas time' and the struggle for the household in the countryside". Journal of Southern African Studies v. 29, n. 3:681-699.

SEEKINCS, Jeremy. 2008 "Deserving Individuals and Croups".

Transformation, v. 68: 28-52.

STANDING, Guy. 2017. Basic Income, and How We Can Make It Happen. London: Pelican Books.

STATISTICS SOUTH AFRICA. 2018. General Household Survey. Published at: http://www.statssa.gov.za/?page_ id $=1854 \& P P N=$ Po318\&SCH $=7652$

\section{SOUTH AFRICAN SOCIAL SECURITY}

AGENCY. 2019. Data compiled by Katherine Hall "Child Support Grants" and published at: http://childrencount.uct.ac.za/ indicator.php?domain=2\&indicator $=10$

THORKELSON, Erin. 2020. "Collateral damages: Cash transfer and debt transfer in South Africa". World Development v.126: 104711
VALLY, Natasha. 2014. "Biometrics and Waiting: An Ethnographic Account of the Biometric Registration and Payment of State Grants in South Africa." Paper presented at the Workshop on Social Protection in Africa, University of Cape Town, May 29-30.

VON SCHNTZLER, Anita. 2015.

Democracy's Infrastructure. Princeton: Princeton University Press.

WEBER, Max 1930. The Protestant Ethic and the Spirit of Capitalism. London: Routledge.

WHITE, Hylton. 2004. "Ritual Haunts" in Brad Weiss (ed). Producing African Futures. Leiden: Brill: 141-166.

WHITE, Hylton. 2010 "Outside the dwelling of culture: estrangement and difference in postcolonial Zululand" Anthropological Quarterly v. 83, n.3: 497-518.

WOLPE, Harold. 1972. "Capitalism and Cheap Labour Power in South Africa" Economy and Society v.1, n. 4: 425-456.

YANG, Andrew 2020 "What is the freedom dividend?". Accessed at: https://www.yang2020. com/what-is-freedom-dividend-faq/

Received on September 30, 2020. Accepted on March 12, 2021. 